\title{
Chemical Equilibria in a Mixed Solution of Nickel and Cobalt Chloride
}

\author{
Man-Seung Lee ${ }^{1}$ and Young-Joo $\mathrm{Oh}^{2}{ }^{2 *}$ \\ ${ }^{1}$ Department of Advanced Materials Science \& Engineering, Mokpo National University, Chonnam 534-729, Korea \\ ${ }^{2}$ Metal Processing Research Center, Korea Institute of Science and Technology, P.O. Box 131, Seoul 136-791, Korea
}

\begin{abstract}
Ionic equilibria in the mixed solution of nickel and cobalt chloride were analyzed by considering the complex formation reactions, the mass and charge balance equations. The activity coefficients of solutes and water activity were calculated by using Bromley equation. Cobalt ion has a strong tendency to form various complexes with chloride ion, such as $\mathrm{CoCl}_{3}{ }^{-}$and $\mathrm{CoCl}_{4}{ }^{2-}$, while $\mathrm{NiCl}^{+}$was the only complex formed between nickel and chloride ion. Distribution of nickel and cobalt species with the compositions and $\mathrm{pH}$ values of the solution was obtained from the analysis of ionic equilibria in the mixed chloride solutions. The predicted $\mathrm{pH}$ values for $\mathrm{NiCl}_{2}-\mathrm{CoCl}_{2}-\mathrm{HCl}-\mathrm{NaOH}-\mathrm{H}_{2} \mathrm{O}$ system agreed well with those measured at $298 \mathrm{~K}$ up to ionic strength of $9.53 \mathrm{~mol} / \mathrm{kg}$.
\end{abstract}

(Received September 28, 2004; Accepted November 24, 2004)

Keywords: $\mathrm{NiCl}_{2}, \mathrm{CoCl}_{2}, \mathrm{HCl}$, ionic equilbira, Bromley

\section{Introduction}

Similarity in the chemical nature of nickel and cobalt has made it difficult to separate the two metals. Many studies have been performed on the solvent extraction separation of nickel and cobalt with various extractants. ${ }^{1-3)}$ The optimum condition to separate the two metals with solvent extraction depends on the various factors, such as the nature of the leaching solution and the concentration ratio of the two metals. In chloride solution, cobalt ion has a strong tendency to form complexes with chloride ion, such as $\mathrm{CoCl}_{2}{ }^{\circ}, \mathrm{CoCl}_{3}{ }^{-}$ and $\mathrm{CoCl}_{4}{ }^{2-}{ }^{4)}$ However, it was found from the speciation of nickel chloride solution that most of nickel is present as $\mathrm{Ni}^{2+}$ and $\left.\mathrm{NiCl}^{+} .5,6\right)$

The difference between nickel and cobalt in the tendency to form chloride complexes was utilized to separate the two metals from chloride solution with an anionic extractant. ${ }^{3)}$ The data on the distribution of nickel and cobalt species with the composition of the mixed chloride solution enable us to analyze the solvent extraction equilibria of nickel and cobalt from chloride solution. We have already reported the ionic equilibria of nickel chloride in $\mathrm{HCl}$ solution. ${ }^{5)}$ We applied Bromley equation to estimate the equilibrium constants for the formation of cobalt chloride complexes and the interaction parameter. ${ }^{4)}$

In this study, we analyzed the ionic equilibria in the mixed solution of nickel and cobalt chloride at high ionic strength. For this purpose, the complex formation reactions, the mass and charge balance equation were considered. The activity coefficients of solutes and water activity were calculated by using Bromley equation. ${ }^{7)}$ Distribution of nickel and cobalt species with the composition of the mixed solution was obtained. The measured $\mathrm{pH}$ values for the $\mathrm{NiCl}_{2}-\mathrm{CoCl}_{2}-\mathrm{HCl}-$ $\mathrm{NaOH}-\mathrm{H}_{2} \mathrm{O}$ system at $298 \mathrm{~K}$ were compared with the calculated values in this study.

\section{Experimental}

Mixed solutions of nickel and cobalt chloride were prepared by dissolving $\mathrm{CoCl}_{2} \cdot 6 \mathrm{H}_{2} \mathrm{O}, \mathrm{NiCl}_{2} \cdot 6 \mathrm{H}_{2} \mathrm{O}, \mathrm{HCl}$ and

${ }^{*}$ Corresponding author, E-mail: oyj@kist.re.kr
$\mathrm{NaOH}$ in distilled water. All chemicals were of reagent grade. First, known amounts of $\mathrm{CoCl}_{2} \cdot 6 \mathrm{H}_{2} \mathrm{O}, \mathrm{NiCl}_{2} \cdot 6 \mathrm{H}_{2} \mathrm{O}, \mathrm{HCl}$ and $\mathrm{NaOH}$ were added to $100 \mathrm{~g}$ of distilled water and then the mixture was stirred with a magnetic stirrer until all the chemicals were dissolved. After all the chemicals were dissolved, the temperature of the solution was controlled to $298 \mathrm{~K}$ by using a water bath. Once the temperature of the solution was stable, solution $\mathrm{pH}$ was measured with a $\mathrm{pH}$ meter (Orion 920A).

\section{Results and Discussion}

\subsection{Chemical model}

Table 1 shows the formation reactions of various nickel complexes considered in this study and the corresponding equilibrium constants at zero ionic strength. ${ }^{8,9)}$ Unlike nickel complexes, the equilibrium constants for the formation of cobalt chloride complexes were reported at different ionic strength of $\mathrm{HClO}_{4}$ medium and are shown in Table 2. ${ }^{8)}$ The formation reaction of $\mathrm{CoCl}^{+}$can be represented by

$$
\mathrm{Co}^{2+}+\mathrm{Cl}^{-}=\mathrm{CoCl}^{+}
$$

The equilibrium constant for eq. (1) at a given ionic strength, $K^{\mathrm{I}}$, is related to the equilibrium constant at zero ionic strength, $K^{0}$, and to the activity coefficient ratio as follows

$$
K^{0}=K^{\mathrm{I}} \frac{\gamma_{\mathrm{CoCl}^{+}}}{\gamma_{\mathrm{Co}^{2+}} \gamma_{\mathrm{Cl}^{-}}}
$$

Taking logarithm on both sides of the above equation and rearrangement of the resulting equation leads to

Table 1 Thermodynamic equilibrium constants for the formation of nickel complexes at $298 \mathrm{~K}$.

\begin{tabular}{lrc}
\hline \multicolumn{1}{c}{ Reaction } & Log $K$ & Reference \\
\hline $\mathrm{Ni}^{2+}+\mathrm{Cl}^{-}=\mathrm{NiCl}^{+}$ & -1.29 & 8 \\
$\mathrm{Ni}^{2+}+\mathrm{OH}^{-}=\mathrm{NiOH}^{+}$ & 4.10 & 9 \\
$\mathrm{Ni}^{2+}+2 \mathrm{OH}^{-}=\mathrm{Ni}(\mathrm{OH})_{2}{ }^{\circ}$ & 8.00 & 9 \\
$2 \mathrm{Ni}^{2+}+\mathrm{OH}^{-}=\mathrm{Ni}_{2} \mathrm{OH}^{3+}$ & 3.30 & 9 \\
$4 \mathrm{Ni}^{2+}+4 \mathrm{OH}^{-}=\mathrm{Ni}_{4}(\mathrm{OH})_{4}{ }^{4+}$ & 28.30 & 9 \\
\hline
\end{tabular}


Table 2 Reported values for the equilibrium constant of cobalt chloride complexes at different ionic strength in the $\mathrm{HClO}_{4}$ medium at $298 \mathrm{~K}$.

\begin{tabular}{crrccc}
\hline Reaction & $\begin{array}{c}\log K^{\mathrm{I}} \\
(I=5)\end{array}$ & $\begin{array}{c}\log K^{\mathrm{I}} \\
(I=7)\end{array}$ & $\begin{array}{c}\log K^{\mathrm{I}} \\
(I=8)\end{array}$ & $\begin{array}{c}\log K^{\mathrm{I}} \\
(I=9)\end{array}$ & $\begin{array}{c}\log K^{\mathrm{I}} \\
(I=10)\end{array}$ \\
\hline $\mathrm{Co}^{2+}+\mathrm{Cl}^{-}=\mathrm{CoCl}^{+}$ & 0.04 & 0.23 & 0.40 & 0.64 & 0.82 \\
$\mathrm{Co}^{2+}+2 \mathrm{Cl}^{-}=\mathrm{CoCl}_{2}{ }^{\circ}$ & -0.62 & -0.15 & 0.30 & 0.78 & 1.26 \\
$\mathrm{Co}^{2+}+3 \mathrm{Cl}^{-}=\mathrm{CoCl}_{3}{ }^{-}$ & -1.40 & -0.70 & 0.02 & 0.80 & 1.60 \\
$\mathrm{Co}^{2+}+4 \mathrm{Cl}^{-}=\mathrm{CoCl}_{4}{ }^{2-}$ & - & - & -0.9 & 0.2 & 1.4 \\
\hline
\end{tabular}

$$
\log K^{\mathrm{I}}=\log K^{0}+\log \gamma_{\mathrm{Co}^{2+}}+\log \gamma_{\mathrm{Cl}^{-}}-\log \gamma_{\mathrm{CoCl}^{+}}
$$

The activity coefficient of solute was calculated by using Bromley equation. The Bromley equation for the activity coefficient of the cation at $298 \mathrm{~K}, \gamma_{\mathrm{M}}$, is represented by the following equations. ${ }^{7)}$

$$
\begin{aligned}
\log \gamma_{\mathrm{M}}= & -\frac{0.5108\left(z_{\mathrm{M}}\right)^{2} I^{0.5}}{1+I^{0.5}}+F_{\mathrm{M}}=-A\left(z_{\mathrm{M}}\right)^{2}+F_{\mathrm{M}} \\
F_{\mathrm{M}}= & \sum_{\mathrm{X}}\left[\frac{\left(0.06+0.6 B_{\mathrm{MX}}\right) \times\left|z_{\mathrm{M}} z_{\mathrm{X}}\right|}{\left(1+\frac{1.5}{\left|z_{\mathrm{M}} z_{\mathrm{X}}\right|} I\right)^{2}}+B_{\mathrm{MX}}\right] \\
& \times \frac{\left(\left|z_{\mathrm{M}}\right|+\left|z_{\mathrm{X}}\right|\right)^{2}}{4}[\mathrm{X}]
\end{aligned}
$$

In the above equations, $z$ is ionic charge and $I$ ionic strength of a solution and $B_{\mathrm{MX}}$ the interaction parameter between cation $\mathrm{M}$ and anion $\mathrm{X}$.

Substitution of the expression for the activity coefficient of each species into eq. (3) gives

$$
\log K^{\mathrm{I}}=\log K^{0}-4 A+F_{\mathrm{Co}^{2+}}+F_{\mathrm{Cl}^{-}}-F_{\mathrm{CoCl}^{+}}
$$

In the $\mathrm{HClO}_{4}$ medium, the concentrations of $\mathrm{Co}^{2+}, \mathrm{Cl}^{-}$ and $\mathrm{CoCl}^{+}$are negligible compared to the $\mathrm{HClO}_{4}$ concentration. ${ }^{10,11)}$ Hence, $\mathrm{F}$ term for the activity coefficient of the anion is related only to the cation $\mathrm{H}^{+}$, while $\mathrm{F}$ term for the activity coefficient of cation is related to the anion $\mathrm{ClO}_{4}{ }^{-}$of the medium. ${ }^{10,11)}$ Substitution of the $\mathrm{F}$ terms for $\mathrm{Co}^{2+}, \mathrm{Cl}^{-}$ and $\mathrm{CoCl}^{+}$into the above equation results in

$$
\begin{aligned}
\log K^{\mathrm{I}}= & \log K^{0}-4 A \\
& +\left[\frac{2\left(0.06+0.6 B_{\mathrm{Co}^{2+}, \mathrm{ClO}_{4}^{-}}\right)}{\left(1+\frac{1.5}{2} I\right)^{2}}+B_{\mathrm{Co}^{2+}, \mathrm{ClO}_{4}^{-}}\right] \\
& \times \frac{9}{4}\left[\mathrm{ClO}_{4}^{-}\right]+\left[\frac{\left(0.06+0.6 B_{\mathrm{H}^{+}, \mathrm{Cl}^{-}}\right)}{(1+1.5 I)^{2}}+B_{\mathrm{H}^{+}, \mathrm{Cl}^{-}}\right] \\
& \times\left[\mathrm{H}^{+}\right]-\left[\frac{\left(0.06+0.6 B_{\mathrm{CoCl}^{+}, \mathrm{ClO}_{4}^{-}}\right)}{(1+1.5 I)^{2}}+B_{\mathrm{CoCl}^{+}, \mathrm{ClO}_{4}^{-}}\right] \\
& \times\left[\mathrm{ClO}_{4}^{-}\right]
\end{aligned}
$$

Bromley reported the value of $B_{\mathrm{Co}^{2+}, \mathrm{ClO}_{4}^{-}}$and $B_{\mathrm{H}^{+}, \mathrm{Cl}^{-}}{ }^{7}{ }^{7}$ Inserting these values together with the concentrations of $\mathrm{H}^{+}$ and $\mathrm{ClO}_{4}{ }^{-}$into eq. (7) resulted in the equations with two

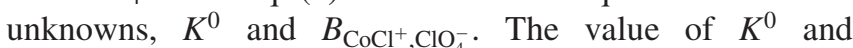
$B_{\mathrm{CoCl}^{+}, \mathrm{ClO}_{4}^{-}}$were estimated by the least square method of these equations. Table 3 represents the equilibrium constants
Table 3 Estimated equilibrium constant and interaction parameter at $298 \mathrm{~K}$.

\begin{tabular}{crcr}
\hline Reaction & $\log K^{0}$ & Interaction parameter & \\
\hline $\mathrm{Co}^{2+}+\mathrm{Cl}^{-}=\mathrm{CoCl}^{+}$ & 0.22 & $B_{\mathrm{CoCl}^{+}, \mathrm{ClO}_{4}^{-}}$ & 0.43 \\
$\mathrm{Co}^{2+}+3 \mathrm{Cl}^{-}=\mathrm{CoCl}_{3}{ }^{-}$ & -3.02 & $B_{\mathrm{H}^{+}, \mathrm{CoCl}_{3}^{-}}$ & 0.25 \\
$\mathrm{Co}^{2+}+4 \mathrm{Cl}^{-}=\mathrm{CoCl}_{4}{ }^{2-}$ & -9.06 & $B_{\mathrm{H}^{+}, \mathrm{CoCl}_{4}^{2-}}$ & -0.05 \\
\hline
\end{tabular}

Table 4 Thermodynamic equilibrium constants for the formation of cobalt complexes at $298 \mathrm{~K}$.

\begin{tabular}{lcc}
\hline \multicolumn{1}{c}{ Reaction } & Log $K$ & Reference \\
\hline $\mathrm{H}^{+}+\mathrm{OH}^{-}=\mathrm{H}_{2} \mathrm{O}$ & 14.0 & 8 \\
$\mathrm{Co}^{2+}+\mathrm{Cl}^{-}=\mathrm{CoCl}^{+}$ & 0.22 & 4 \\
$\mathrm{Co}^{2+}+2 \mathrm{Cl}^{-}=\mathrm{CoCl}_{2}{ }^{\circ}$ & -3.95 & 4 \\
$\mathrm{Co}^{2+}+3 \mathrm{Cl}^{-}=\mathrm{CoCl}_{3}{ }^{-}$ & -3.02 & 4 \\
$\mathrm{Co}^{2+}+4 \mathrm{Cl}^{-}=\mathrm{CoCl}_{4}{ }^{2-}$ & -9.06 & 4 \\
$\mathrm{Co}^{2+}+\mathrm{OH}^{-}=\mathrm{CoOH}^{+}$ & 4.30 & 8 \\
$\mathrm{Co}^{2+}+2 \mathrm{OH}^{-}=\mathrm{Co}(\mathrm{OH})_{2}{ }^{\circ}$ & 8.40 & 8 \\
$2 \mathrm{Co}^{2+}+\mathrm{OH}^{-}=\mathrm{Co}_{2} \mathrm{OH}{ }^{3+}$ & 2.70 & 8 \\
$4 \mathrm{Co}^{2+}+4 \mathrm{OH}^{-}=\mathrm{Co}_{4}(\mathrm{OH})_{4}{ }^{4+}$ & 25.60 & 8 \\
\hline
\end{tabular}

and interaction parameters obtained by this procedure. ${ }^{4)}$ Table 4 lists the equilibrium constants for the formation of cobalt complexes.

Since activity coefficients of electrically neutral species could not be calculated with Bromley equation, the activity coefficients of $\mathrm{CoCl}_{2}{ }^{\circ}, \mathrm{Co}(\mathrm{OH})_{2}{ }^{\circ}$ and $\mathrm{Ni}(\mathrm{OH})_{2}{ }^{\circ}$ were assumed to be unity.

The water activity for a single electrolyte $\mathrm{ij}, a_{\mathrm{W}, i j}^{\circ}$, was calculated using the following Bromley equation for the osmotic coefficient, $\phi_{i j}:{ }^{12)}$

$$
\begin{aligned}
& \phi_{i j}=1-2.303\left[\frac { 0 . 5 1 0 8 | z _ { i } z _ { j } | } { I } \left\{1+\sqrt{I}-\frac{1}{1+\sqrt{I}}\right.\right. \\
& -2 \ln (1+\sqrt{I})\}-\frac{\left(0.06+0.6 B_{i j}\right) \times\left|z_{i} z_{j}\right|}{\frac{1.5}{\left|z_{i} z_{j}\right|}} \\
& \left.\times\left\{\frac{1+2 \frac{1.5}{\left|z_{i} z_{j}\right|} I}{\left(1+\frac{1.5}{\left|z_{i} z_{j}\right|} I\right)^{2}}-\frac{\ln \left(1+\frac{1.5}{\left|z_{i} z_{j}\right|} I\right)}{\frac{1.5}{\left|z_{i} z_{j}\right|} I}\right\}-0.5 B_{i j} I\right] \\
& \ln a_{\mathrm{W}, i j}^{\circ}=-\frac{18.02 v m}{1000} \phi_{i j}
\end{aligned}
$$

where $v$ represents the number of moles of ions and $m$, the molality of the electrolyte.

The water activity of the mixed electrolyte solutions was calculated from the water activity of a single electrolyte with the following equation suggested by Meissner. ${ }^{12)}$

$$
\ln a_{\mathrm{W}, \text { mix }}=\sum \sum \frac{I_{i} I_{j}}{I^{2}}\left[\frac{\left(\left|z_{i}\right|+\left|z_{j}\right|\right)^{2}}{\left|z_{i} z_{j}\right|}\right] \times \ln a_{\mathrm{W}, i j}^{\circ}
$$


where $I_{i}$ represents the ionic strength of the individual ions, which equals $0.5 m_{i}\left(z_{i}\right)^{2}$.

For the $\mathrm{NiCl}_{2}-\mathrm{CoCl}_{2}-\mathrm{HCl}-\mathrm{NaOH}-\mathrm{H}_{2} \mathrm{O}$ system, the following mass and charge balance equations were obtained from the complex formation reactions shown in Tables 1 and 4 .

$$
\begin{aligned}
{[\mathrm{Co}]_{t}=} & {\left[\mathrm{Co}^{2+}\right]+\left[\mathrm{CoCl}^{+}\right]+\left[\mathrm{CoCl}_{2}^{\circ}\right]+\left[\mathrm{CoCl}_{3}{ }^{-}\right] } \\
& +\left[\mathrm{CoCl}_{4}^{2-}\right]+\left[\mathrm{CoOH}^{+}\right]+\left[\mathrm{Co}(\mathrm{OH})_{2}{ }^{\circ}\right] \\
& +2\left[\mathrm{Co}_{2} \mathrm{OH}^{3+}\right]+4\left[\mathrm{Co}_{4}(\mathrm{OH})_{4}{ }^{4+}\right] \\
{[\mathrm{Ni}]_{t}=} & {\left[\mathrm{Ni}^{2+}\right]+\left[\mathrm{NiCl}^{+}\right]+\left[\mathrm{NiOH}^{+}\right]+\left[\mathrm{Ni}(\mathrm{OH})_{2}{ }^{\circ}\right] } \\
& +2\left[\mathrm{Ni}_{2} \mathrm{OH}^{3+}\right]+4\left[\mathrm{Ni}_{4}(\mathrm{OH})_{4}^{4+}\right] \\
{[\mathrm{Cl}]_{t}=} & {\left[\mathrm{Cl}^{-}\right]+\left[\mathrm{CoCl}^{+}\right]+2\left[\mathrm{CoCl}_{2}{ }^{\circ}\right]+3\left[\mathrm{CoCl}_{3}{ }^{-}\right] } \\
& +4\left[\mathrm{CoCl}_{4}{ }^{2-}\right]+\left[\mathrm{NiCl}^{+}\right] \\
{[\mathrm{Na}]_{t}=} & {\left[\mathrm{Na}^{+}\right] }
\end{aligned}
$$

In the above equations, subscript $t$ represents the total concentration.

$$
\begin{aligned}
{\left[\mathrm{H}^{+}\right] } & +2\left[\mathrm{Co}^{2+}\right]+\left[\mathrm{CoCl}^{+}\right]+\left[\mathrm{CoOH}^{+}\right] \\
& +3\left[\mathrm{Co}_{2} \mathrm{OH}^{3+}\right]+4\left[\mathrm{Co}_{4}(\mathrm{OH})_{4}^{4+}\right]+\left[\mathrm{Na}^{+}\right] \\
& +2\left[\mathrm{Ni}^{2+}\right]+\left[\mathrm{NiCl}^{+}\right]+\left[\mathrm{NiOH}^{+}\right]+3\left[\mathrm{Ni}_{2} \mathrm{OH}^{3+}\right] \\
& +4\left[\mathrm{Ni}_{4}(\mathrm{OH})_{4}{ }^{4+}\right]=\left[\mathrm{Cl}^{-}\right]+\left[\mathrm{CoCl}_{3}{ }^{-}\right] \\
& +2\left[\mathrm{CoCl}_{4}{ }^{2-}\right]+\left[\mathrm{OH}^{-}\right]
\end{aligned}
$$

In the $\mathrm{NiCl}_{2}-\mathrm{CoCl}_{2}-\mathrm{HCl}-\mathrm{NaOH}-\mathrm{H}_{2} \mathrm{O}$ system, there were 19 solutes in the equilibrium state, i.e., $\left[\mathrm{Co}^{2+}\right],\left[\mathrm{CoCl}^{+}\right]$, $\left[\mathrm{CoCl}_{2}{ }^{\circ}\right],\left[\mathrm{CoCl}_{3}{ }^{-}\right],\left[\mathrm{CoCl}_{4}{ }^{2-}\right],\left[\mathrm{CoOH}^{+}\right],\left[\mathrm{Co}(\mathrm{OH})_{2}{ }^{\circ}\right]$, $\left[\mathrm{Co}_{2} \mathrm{OH}^{3+}\right],\left[\mathrm{Co}_{4}(\mathrm{OH})_{4}{ }^{4+}\right],\left[\mathrm{Ni}^{2+}\right],\left[\mathrm{NiCl}^{+}\right],\left[\mathrm{NiOH}^{+}\right]$, $\left[\mathrm{Ni}(\mathrm{OH})_{2}{ }^{\circ}\right],\left[\mathrm{Ni}_{2} \mathrm{OH}^{3+}\right],\left[\mathrm{Ni}_{4}(\mathrm{OH})_{4}^{4+}\right],\left[\mathrm{H}^{+}\right],\left[\mathrm{Na}^{+}\right],\left[\mathrm{Cl}^{-}\right]$ and $\left[\mathrm{OH}^{-}\right]$. In order to calculate the equilibrium concentrations and activity coefficients of these 19 solutes and water activity, 39 independent equations were needed. These independent equations were obtained from 14 complex formation reactions shown in Tables 1 and 4, 4 mass balance equations, a charge balance equation, 19 activity coefficient equations of solute and the activity equation of water. These equations were solved by Newton-Raphson method.

Table 5 shows the experimental compositions of the $\mathrm{NiCl}_{2}-\mathrm{CoCl}_{2}-\mathrm{HCl}-\mathrm{NaOH}-\mathrm{H}_{2} \mathrm{O}$ system together with the $\mathrm{pH}$ values measured at $298 \mathrm{~K}$, in which the unit of concentration is molality. Also the $\mathrm{pH}$ values and ionic strength calculated in this study are shown in this table. Both measured and calculated $\mathrm{pH}$ values are shown in Fig. 1. From Table 5 and Fig. 1, it is known that the experimental $\mathrm{pH}$ values are in good agreement with the calculated values up to ionic strength of $9.53 \mathrm{~mol} / \mathrm{kg}$.

\subsection{Distribution of chemical species}

Figure 2 shows the distribution of cobalt chloride complexes with $\mathrm{HCl}$ concentration in the absence and presence of $1.0 \mathrm{~mol} / \mathrm{kg} \mathrm{NiCl}_{2}$, when $\mathrm{CoCl}_{2}$ concentration was $1.0 \mathrm{~mol} /$ $\mathrm{kg}$. It is seen in Fig. 2 that most of cobalt exists as cobalt ion and the mole fraction of the cobalt ion is nearly constant up to $3.0 \mathrm{~mol} / \mathrm{kg} \mathrm{HCl}$. The mole fraction of $\mathrm{CoCl}^{+}$decreased with increasing $\mathrm{HCl}$ concentration, while that of $\mathrm{CoCl}_{2}{ }^{\circ}, \mathrm{CoCl}_{3}{ }^{-}$ and $\mathrm{CoCl}_{4}{ }^{2-}$ increased with increasing $\mathrm{HCl}$ concentration. The mole fraction of cobalt chloride complexes decreased in the following order, $\mathrm{Co}^{2+}>\mathrm{CoCl}^{+}>\mathrm{CoCl}_{3}^{-}>$ $\mathrm{CoCl}_{2}{ }^{\circ}>\mathrm{CoCl}_{4}{ }^{2-}$. The presence of $\mathrm{NiCl}_{2}$ enhanced the
Table 5 Compositions of synthetic mixed chloride solution of nickel and cobalt and calculated results.

\begin{tabular}{rcccccrc}
\hline $\mathrm{N}$ & {$\left[\mathrm{CoCl}_{2}\right]_{t}$} & {$\left[\mathrm{NiCl}_{2}\right]_{t}$} & {$[\mathrm{HCl}]_{t}$} & {$[\mathrm{NaOH}]_{t}$} & $\mathrm{pH}$ & \multicolumn{1}{c}{$\mathrm{pH}_{\mathrm{C}}$} & $I_{\mathrm{C}}$ \\
\hline 1 & 0.1 & 0.1 & 0.1 & 0 & 1.22 & 1.14 & 0.67 \\
2 & 0.1 & 0.1 & 0.5 & 0.4 & 1.17 & 1.11 & 1.06 \\
3 & 0.1 & 0.1 & 1.0 & 0.9 & 1.15 & 1.07 & 1.54 \\
4 & 0.1 & 0.1 & 1.5 & 0.9 & 0.36 & 0.24 & 2.02 \\
5 & 0.1 & 0.1 & 2.0 & 2.1 & 6.44 & 6.48 & 2.57 \\
6 & 1.0 & 1.0 & 1.0 & 0.5 & 0.03 & 0.03 & 5.53 \\
7 & 1.0 & 1.0 & 1.0 & 0.8 & 0.23 & 0.43 & 5.56 \\
8 & 1.0 & 1.0 & 1.0 & 1.3 & 5.67 & 5.78 & 5.84 \\
9 & 1.0 & 1.0 & 1.5 & 0.8 & -0.18 & -0.17 & 5.90 \\
10 & 1.0 & 1.0 & 2.0 & 2.2 & 5.43 & 5.48 & 6.54 \\
11 & 1.5 & 1.5 & 0.1 & 0 & 0.47 & 0.66 & 6.59 \\
12 & 1.5 & 1.5 & 1.0 & 0.5 & -0.17 & -0.14 & 7.15 \\
13 & 1.5 & 1.5 & 1.0 & 1.3 & 5.30 & 5.23 & 7.54 \\
14 & 1.5 & 1.5 & 1.5 & 0.8 & -0.43 & -0.34 & 7.47 \\
15 & 1.5 & 1.5 & 2.0 & 1.0 & -0.48 & -0.55 & 7.76 \\
16 & 2.0 & 2.0 & 0.1 & 0 & 0.34 & 0.50 & 7.95 \\
17 & 2.0 & 2.0 & 1.0 & 0.5 & -0.31 & -0.29 & 8.42 \\
18 & 2.0 & 2.0 & 1.5 & 0.8 & -0.51 & -0.48 & 8.67 \\
19 & 2.0 & 2.0 & 2.0 & 1.9 & 0.08 & 0.30 & 9.07 \\
20 & 2.0 & 2.0 & 2.0 & 2.3 & 4.88 & 4.66 & 9.53 \\
\hline
\end{tabular}

$(\mathrm{N}$ : number,

$\mathrm{pH}$ : measured values of $\mathrm{pH}$,

$\mathrm{pH}_{\mathrm{C}}$ : calculated values of $\mathrm{pH}$,

$I_{\mathrm{C}}$ : calculated values of ionic strength)

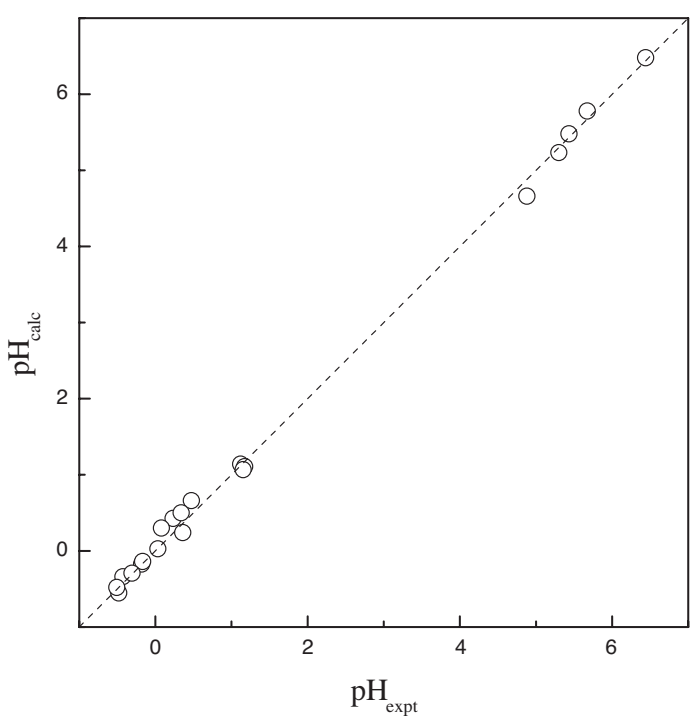

Fig. 1 Comparison of $\mathrm{pH}$ values between measured and calculated in this study.

complex formation of $\mathrm{CoCl}_{2}{ }^{\circ}, \mathrm{CoCl}_{3}{ }^{-}$and $\mathrm{CoCl}_{4}{ }^{2-}$, while the mole fraction of $\mathrm{CoCl}^{+}$decreased in the presence of $\mathrm{NiCl}_{2}$.

Figure 3 shows the variation in the mole fraction of $\mathrm{Ni}^{2+}$ and $\mathrm{NiCl}^{+}$with $\mathrm{HCl}$ concentration in the absence and presence of $1.0 \mathrm{~mol} / \mathrm{kg} \mathrm{CoCl}$, when $\mathrm{NiCl}_{2}$ concentration was $1.0 \mathrm{~mol} / \mathrm{kg}$. Most of nickel existed as nickel ion in the concentration range of up to $3.0 \mathrm{~mol} / \mathrm{kg} \mathrm{HCl}$. The mole fraction of nickel ion decreased slightly with increasing $\mathrm{HCl}$ 


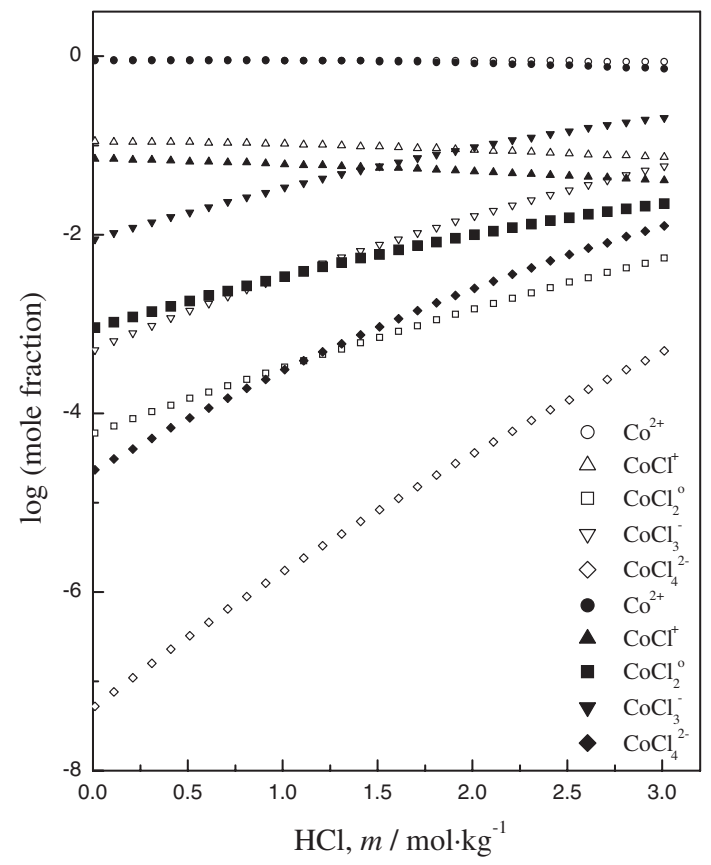

Fig. 2 Effect of $\mathrm{HCl}$ and $\mathrm{NiCl}_{2}$ concentration on the distribution of cobalt chloride complexes at $1.0 \mathrm{~mol} / \mathrm{kg} \mathrm{CoCl}_{2}$ concentration. (Open: without $\mathrm{NiCl}_{2}$, Closed: in the presence of $1.0 \mathrm{~mol} / \mathrm{kg} \mathrm{NiCl} 2$ )

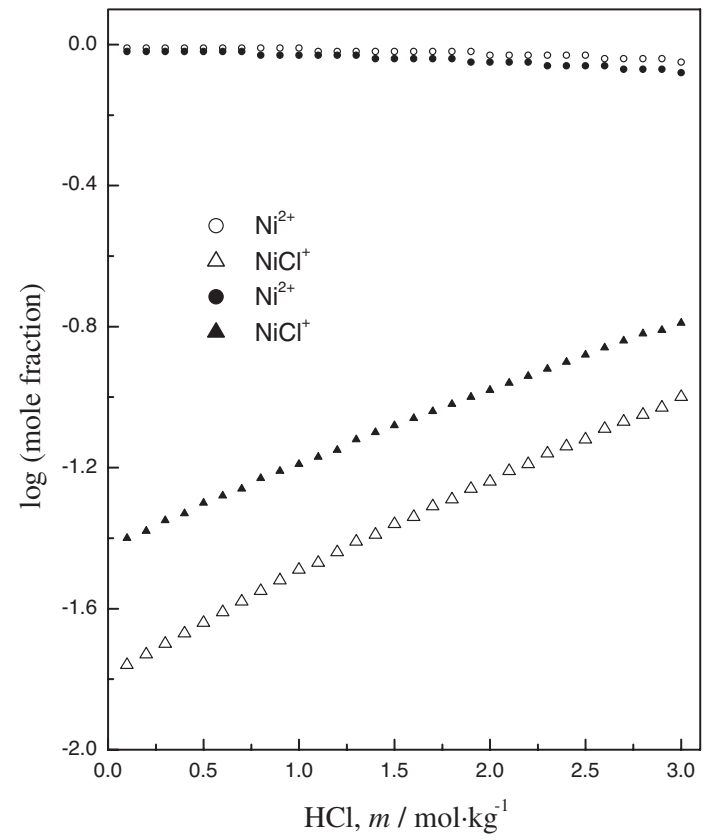

Fig. 3 Effect of $\mathrm{HCl}$ and $\mathrm{CoCl}_{2}$ concentration on the distribution of nickel species at $1.0 \mathrm{~mol} / \mathrm{kg} \mathrm{NiCl}_{2}$ concentration. (Open: without $\mathrm{CoCl}_{2}$, Closed: in the presence of $1.0 \mathrm{~mol} / \mathrm{kg} \mathrm{CoCl}{ }_{2}$ )

concentration, while that of $\mathrm{NiCl}^{+}$increased greatly with increasing $\mathrm{HCl}$ concentration. The presence of $\mathrm{CoCl}_{2}$ increased the mole fraction of $\mathrm{NiCl}^{+}$but decreased slightly the mole fraction of nickel ion.

Figure 4 shows the distribution of cobalt species with solution $\mathrm{pH}$ in the mixed solution of $1.0 \mathrm{~mol} / \mathrm{kg} \mathrm{CoCl} 2$ and $1.0 \mathrm{~mol} / \mathrm{kg} \mathrm{NiCl}_{2}$. In the $\mathrm{pH}$ range of 0 to 6 , most of cobalt existed as cobalt ion and the mole fraction of cobalt chloride complexes decreased with solution $\mathrm{pH}$ in the following order,

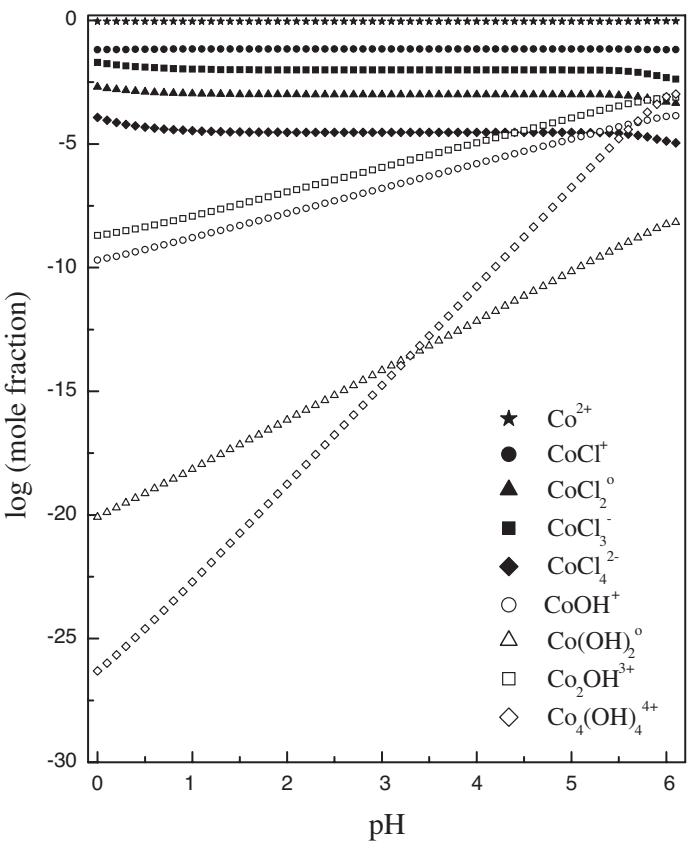

Fig. 4 Distribution of cobalt species with the $\mathrm{pH}$ of mixed chloride solution. $\left(\left[\mathrm{CoCl}_{2}\right]_{t}=1.0 \mathrm{~mol} / \mathrm{kg},\left[\mathrm{NiCl}_{2}\right]_{t}=1.0 \mathrm{~mol} / \mathrm{kg}\right)$

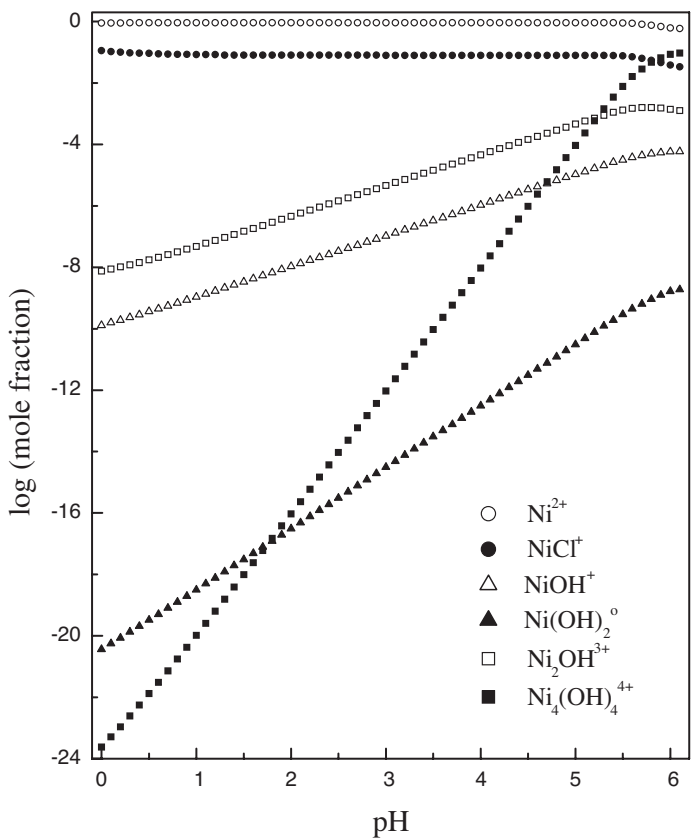

Fig. 5 Distribution of nickel species with the $\mathrm{pH}$ of mixed chloride solution. $\left(\left[\mathrm{CoCl}_{2}\right]_{t}=1.0 \mathrm{~mol} / \mathrm{kg},\left[\mathrm{NiCl}_{2}\right]_{t}=1.0 \mathrm{~mol} / \mathrm{kg}\right)$

$\mathrm{CoCl}^{+}>\mathrm{CoCl}_{3}{ }^{-}>\mathrm{CoCl}_{2}{ }^{\circ}>\mathrm{CoCl}_{4}{ }^{2-}$. The mole fraction of cobalt hydroxide complexes increased greatly with solution $\mathrm{pH}$ in the following order, $\mathrm{Co}_{2} \mathrm{OH}^{3+}>\mathrm{CoOH}^{+}>$ $\mathrm{Co}_{4}(\mathrm{OH})_{4}{ }^{4+}>\mathrm{Co}_{2}(\mathrm{OH})_{2}{ }^{\circ}$, when solution $\mathrm{pH}$ was higher than 3.2 .

Figure 5 shows the distribution of nickel species with solution $\mathrm{pH}$ in the mixed solution of $1.0 \mathrm{~mol} / \mathrm{kg} \mathrm{CoCl} 2$ and $1.0 \mathrm{~mol} / \mathrm{kg} \mathrm{NiCl}_{2}$. Most of nickel existed as nickel ion in the $\mathrm{pH}$ range of 0 to 6 . The mole fraction of nickel hydroxide 
complexes increased greatly with increasing solution $\mathrm{pH}$ in the following order, $\mathrm{Ni}_{2} \mathrm{OH}^{3+}>\mathrm{NiOH}^{+}>\mathrm{Ni}_{4}(\mathrm{OH})_{4}{ }^{4+}>$ $\mathrm{Ni}(\mathrm{OH})_{2}{ }^{\circ}$, when the value of solution $\mathrm{pH}$ was between 2.0 and 4.5. Among the nickel hydroxide complexes, the mole fraction of $\mathrm{Ni}_{4}(\mathrm{OH})_{4}{ }^{4+}$ increased greatly with solution $\mathrm{pH}$ and was higher than that of $\mathrm{NiCl}^{+}$, when solution $\mathrm{pH}$ was higher than 6.0.

\section{Conclusions}

Ionic equilibria in the mixed solution of nickel and cobalt chloride were analyzed by considering the complex formation reaction, the mass balance equations and a charge balance equation. The activity coefficients of solutes and water activity were calculated by using Bromley equation. In the $\mathrm{pH}$ range of -0.5 to 6.4 , the measured $\mathrm{pH}$ values for the $\mathrm{NiCl}_{2}-\mathrm{CoCl}_{2}-\mathrm{HCl}-\mathrm{NaOH}-\mathrm{H}_{2} \mathrm{O}$ system at $298 \mathrm{~K}$ agreed well with the calculated values up to ionic strength of $9.53 \mathrm{~mol} /$ $\mathrm{kg}$. Distribution of nickel and cobalt species with the composition and solution $\mathrm{pH}$ was obtained by analyzing the ionic equilibria.

\section{REFERENCES}

1) N. B. Devi, K. C. Nathsarma and V. Chakravortty: Hydrometallurgy 49 (1998) 47-61.

2) K. Sarangi, B. R. Reddy and R. P. Das: Hydrometallurgy 52 (1999) 253-265.

3) J. G. Ahn, J. W. Ahn and M. S. Lee: J. Kor. Inst. Met. \& Mater. 40 (2002) 799-804.

4) M. S. Lee and Y. J. Oh: Mater. Trans. 45 (2004) 1317-1321.

5) M. S. Lee and G. S. Lee: J. Kor. Inst. Resources Recycling 12 (2003) $38-45$.

6) J. X. Ji and W. C. Cooper: Electrochimica Acta 41 (1996) 1549-1560

7) L. A. Bromley: AIChE J. 19 (1973) 313-320.

8) E. Högfeldt: Stability constants of Metal-Ion Complexes, Part A. Inorganic ligands, (Pergamon, Oxford, 1982).

9) R. M. Smith and A. E. Martell: Stability constants: Inorganic complexes, (Plenum Press, 1982) p. 4.

10) J. C. Raposo, J. Sanz, G. Borge, M. A. Olazabal and J. M. Madariaga: Fluid Phase Equilibria 155 (1999) 1-19.

11) Y. Belaustegi, M. A. Olazabal and J. M. Madariaga: Fluid Phase Equilibria 155 (1999) 21-31.

12) J. F. Zemaitis, D. M. Clark, M. Rafal and N. C. Scrivner: Handbook of aqueous electrolyte thermodynamics, A publication of the Design Institute for Physical Property Data, NY (1986) pp. 600-602. 